Sanda Lucija Udier

Faculty of Humanities and Social Sciences

University of Zagreb

sludier@ffzg.hr

\section{Darko Matovac}

Faculty of Humanities and Social Sciences

University of Zagreb

dmatovac@ffzg.hr
UDK 811.163.42'367.625:37.091.3

DOI: $10.4312 /$ vestnik.9.173-189

\title{
IN WHICH ORDER SHOULD VERBAL PREFIXATION IN CROATIAN AS L2 BE TAUGHT?
}

When it comes to teaching Croatian as a second and foreign language (CL2) certain aspects of the process seem more demanding than others, equally from the perspective of a teacher as from the perspective of a student. Verbal prefixation is surely among the more complicated ones as confirmed by the number of mistakes students make while using prefixed verbs in their oral and written production. It is difficult to teach prefixed verbs as the descriptions of the process of verbal prefixation in contemporary Croatian grammar books are not accurate enough, at least not enough to be applied in CL2 contexts. As a support to this claim, it can be pointed out that contemporary Croatian grammar books cannot even agree on the number of verbal prefixes, e.g. Babić (2002: 536) claims that altogether there are 28 verbal prefixes in Croatian, of which 18 are productive and five less productive, while Silić and Pranjković (2005: 147-149) list 21 and Barić et al. (1997: 380-384) 19 prefixes. Furthermore, a semantic description of a verbal prefix can differ significantly from one grammar book to another, e.g. Barić et al. (2005: 383) claim that the verbal prefix pred-has one meaning, while Silić and Pranjković (2005: 148) claim that the same prefix has five different meanings. Such differing descriptions, which mostly rely on a native-like understanding of the language, are surely not adequate in the context of CL2 teaching and learning. Consequently, most of the CL2 textbooks that do deal with this topic more or less systematically - and a lot of them actually avoid this topic completely_resort to teaching prefixed verbs lexically. ${ }^{1}$ Unfortunately, in doing so

1 More detailed discussion on the two existing approaches to teaching verbal prefixation in CL2 - lexical prefixcentric approach and the verbs in context approach - can be found in Matovac and Udier (2016a). 
they fail to present verbal prefixation as a productive and semantically motivated process, which makes it especially difficult to master for students of CL2. Hence the need for a new and more effective approach to teaching verbal prefixation came about (Matovac 2015; Matovac and Udier 2016a).

THEORETICAL FRAMEWORK AND PREVIOUS RESEARCH

The new teaching approach ideally should be based on the descriptions of verbal prefixation produced within the cognitive linguistic theoretical framework as those descriptions have been proven to be more detailed and more accessible than the traditional descriptions as well as succeeding in depicting the process of verbal prefixation as a semantically motivated and structured one. There are reasons to believe that the approach to teaching verbal prefixation in CL2 envisioned within this theoretical framework, labelled therefore as the cognitive linguistic approach, will facilitate more efficient teaching as it will be able to present verbal prefixation in a more tenable, structured and concrete manner. Consequently, CL2 students taught using this approach will be more certain in their use of prefixed verbs as well as able to understand verbal prefixation as a productive process which has explainable rather than random limitations, i.e. CL2 students taught using this approach will be aware that the semantic compatibility between a base verb and a verbal prefix is a crucial factor in the process of a prefixed verb's formation. More detailed discussion on this approach to teaching verbal prefixation can be read in Matovac and Udier (2016a) while the first results achieved with its application in CL2 classroom, which are positive, can be found in Matovac and Udier (2016b). However, further research should be carried out in order to properly describe all the different factors that influence the attainment of prefixed verbs among CL2 learners if the new approach is to be entirely successful and based not only on theoretical assumptions but on their empirical validation as well. The results of such research need to be incorporated into the new teaching approach's design.

Several such studies have already been conducted. The one conducted by Udier and Matovac (2017) focused on frequency and it confirmed its effects on the attainment of prefixed verbs in the following ways: (1) the more frequent a prefixed verb is, the better it will be attained, (2) the more frequent a verbal prefix is, the better verbs prefixed by it will be attained, (3) the more frequently a preposition follows its cognate verbal prefix, the better verbs prefixed by that prefix will be attained and (4) the more frequent a preposition is, the better verbs prefixed by its cognate verbal prefix will be attained. In the same way, the research conducted by Udier, Mikelić Preradović and Boras (2017) showed that the acquisition of a prefixed verb is more systematic if the verb is followed by a preposition cognate to the verbal prefix used, and, consequently, that the acquisition is less systematic if the verb is not followed by the cognate preposition. The two researches put forward the 
conclusion that an understanding of the preposition cognate to the verbal prefix should be considered key for its understanding and, as a result, for the accurate usage of verbs formed by that verbal prefix. The research presented in this paper proceeds on the path laid out by Udier, Mikelić Preradović and Boras (2017) and Udier and Matovac (2017) as it seeks to illuminate further the connection between verbal prefixes and prepositions, but on a much larger scale and with a different goal. This research aims to propose the order in which verbal prefixes should be taught in connection with whether a verbal prefix has a cognate preposition and whether the cognate preposition follows the verbal prefix. The order of teaching proposed by this research should make the process of teaching verbal prefixation as effective as possible and it should help in making the acquired knowledge as productive as possible.

This research starts off from the assumption that an understanding of the meaning of a verbal prefix is strongly supported by understanding the meaning of its cognate preposition and that this fact can serve as the cornerstone in the process of teaching verbal prefixes. The meaning of a preposition is of crucial importance as CL2 students learn prepositions chronologically much earlier than they learn prefixed verbs, i.e. when they start to learn prefixed verbs they have already been acquainted with the meanings of all prepositions that have cognate verbal prefixes, and that helps them significantly in interpreting the meaning of verbs formed by those verbal prefixes.

\section{3}

\section{RESEARCH HYPOTHESIS}

Based on the results of the aforementioned research as well as on the theoretical framework, it can be assumed that the progression of teaching prefixed verbs in CL2 should start off from the prototypical examples, i.e. from prefixed verbs which are transparent both in form and meaning, while semantically more opaque verbs should follow later (if their frequency in everyday language does not dictate that they should be learned much sooner; in that case they should be taught lexically). Furthermore, it can be assumed that verbs prefixed by a verbal prefix which has a cognate preposition are semantically more transparent for CL2 students and, consequently, should be taught sooner. If the cognate preposition follows the prefixed verb when used in a sentence, it helps CL2 students even more to understand the meaning of a prefixed verb, so such examples should be the starting point in the process of teaching. Finally, it can be assumed that verbs prefixed by a verbal prefix which has no cognate preposition will be semantically least transparent for CL2 students and therefore such prefixed verbs should be taught later. To test these assumptions, research was conducted with the following basic hypothesis set out to be proven - the attainment of prefixed verbs is directly related to whether a verbal prefix has a cognate preposition and whether that preposition follows the prefixed verb in the sentence, e.g. the verb izići 'to go out, leave' will be better attained than the verb razići se 
'to split up' as the verbal prefix iz- used in izići has a cognate preposition $i z$ 'out' and that preposition frequently follows the verb izići when used in a sentence, e.g. Elvis je izišao iz zgrade 'Elvis has left the building', while the verbal prefix raz- has no cognate preposition at all. From this basic hypothesis, the following more detailed hypotheses came about:

H1: The best attained prefixed verbs are those formed by a verbal prefix which has a cognate preposition and that frequently occur in a sentence with that cognate preposition following them, e.g. sići 'to get off, get down' in Mačka je sišsla $\underline{s}$ krova 'The cat got down from the roof'.

H2: Prefixed verbs formed by a verbal prefix which has a cognate preposition, but that never occur in a sentence with that cognate preposition following them, will be less well attained than prefixed verbs formed by a verbal prefix which has a cognate preposition and that frequently occur in a sentence with that cognate preposition following them, e.g. spakirati never appears followed by the preposition $s$ 'off, with' and therefore it will be more poorly attained than the verb sić $i$ 'get off, get down' which frequently appears followed by $s$ 'off, with'.

H3: Among prefixed verbs formed by a verbal prefix which has a cognate preposition but that never occur in a sentence with that cognate preposition following, verbs prefixed by a verbal prefix which more frequently co-occurs with its cognate preposition will be better attained, e.g. verbs like spakirati 'to pack' will be better attained than verbs such as nadigrati 'to outplay' because there are verbs formed by the verbal prefix $s$ - and followed by the preposition $s$ 'off, with', while there are no verbs formed by nad- which appear followed by the preposition nad 'over, above'.

H4: Prefixed verbs formed by a verbal prefix which does not have a cognate preposition will be the least well attained even if a preposition with a meaning similar to the meaning of the verbal prefix exists, e.g. verbs formed by raz-will be poorly attained because it has no cognate preposition, just as verbs formed by pro- will be, even though the preposition kroz 'through' has a similar meaning and often follows pro- verbs when used in a sentence, e.g. Vlak je prošao $\underline{\mathrm{kroz}}$ tunel 'The train passed through the tunnel'.

\section{RESEARCH SAMPLE AND METHODOLOGICAL ISSUES}

The research was conducted among 47 participants, students of CL2, who attended Croaticum - Centre for Croatian as a Second and Foreign Language at the University of Zagreb during the academic year of 2016/2017. Their levels of CL2 proficiency were B2 and C1 (29 participants were at a B2 level while 18 were at a C1 level). Such high levels 
of CL2 proficiency were chosen for this research because students on lower levels of language proficiency cannot be valid research participants as they are still not competent enough in their use of prefixed verbs (on lower levels of language proficiency only the most frequent prefixed verbs are being taught).

Several concerns have been brought up during the course of this research. One of them was that there was a rather small research sample of only 47 participants. Within the time-frame of this research it was not possible to overcome this problem as Croatian belongs to the group of less commonly taught and learned languages, which makes research participants, especially those at high levels of language proficiency, hard to find. Further concern had to do with the length of the questionnaire, as it was rather extensive, which was not avoidable as the number of verbal prefixes that needed to be examined was large. Additionally, each of the verbal prefixes had to be tested through several test items because the research results needed to show the attainment of a verbal prefix itself, and not the attainment of a specific prefixed verb. The extensiveness of the questionnaire might have caused fatigue and poor concentration among the research participants.

It should be pointed out that all participants were taught about verbal prefixation during their studies at lower levels of CL2 proficiency and that there is a possibility that the teaching approach they were exposed to could have influenced the results of this research. Nevertheless, it is impossible to exclude this factor other than by conducting a longitudinal research, which is very hard to accomplish as Croatian belongs to the group of less commonly taught and learned languages and it is therefore challenging to find reliable participants for this kind of research.

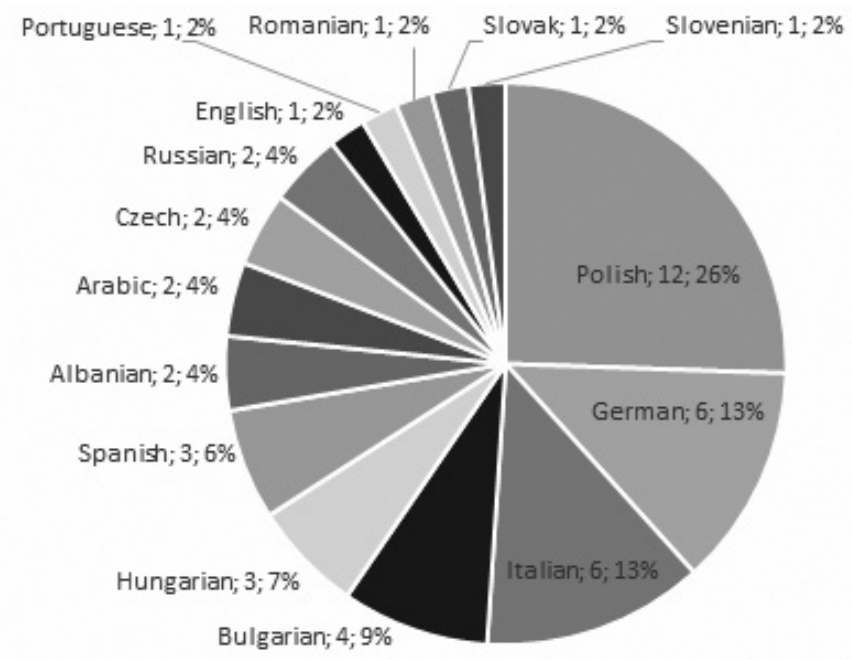

Figure 1: L1 of research participants 
The first languages of the participants and number of speakers of each of the languages were as presented in Figure 1. The research sample was moderately even - there was altogether $47 \%$ non-Slavic L1 participants while $53 \%$ of participants had a Slavic language as their L1. The ratio of non-Slavic and Slavic L1 participants should be interpreted as not influencing the results of the research, but the differences in the attainment of prefixed verbs between Slavic (and especially the Polish among the other Slavic speakers) and non-Slavic CL2 students need to be investigated in further research.

A questionnaire consisting of 60 test items was created for the purposes of this research, with 15 test items for each of the four categories of prefixed verbs. The research participants were instructed to choose a prefixed verb, out of the four offered, which they considered fitting in each of the test items given in the questionnaire. A test item consisted of a sentence retrieved from the hrWaC corpus (Ljubešić and Erjavec 2011), which was used to determine the token frequency of prefixed verbs and verbal prefixes as well. The attainment of a verbal prefix was defined as the percentage of correctly given answers for each of the verbal prefixes in each of the four groups of verbs included in the study.

The first group of prefixed verbs comprised verbs prefixed by verbal prefixes which have cognate prepositions and that frequently occur in a sentence with the cognate prepositions following them. The second group of prefixed verbs comprised verbs prefixed by verbal prefixes which have cognate prepositions but that never occur in a sentence with cognate prepositions following them (though there are other verbs prefixed by those verbal prefixes which do appear with cognate prepositions following). Verbs in the first and second group were prefixed by $n a-, o d-, s-, u$ - and $z a-$. The third group of prefixed verbs comprised verbs prefixed by verbal prefixes which have cognate prepositions but that (almost) never ${ }^{2}$ occur in a sentence with those cognate prepositions following. Verbs in that group were prefixed by nad-, o-, po-, pred-and pri-. The fourth group of prefixed verbs comprised verbs prefixed by verbal prefixes which do not have cognate prepositions. Those verbal prefixes are $o b-{ }^{3}$ pre-, pro-, su- and $r a z$-. Table 1 presents the four groups of prefixed verbs together with their features.

2 It's important to point out that usages where the preposition follows those prefixed verbs exist, such as the phrase objesiti kopačke o klin 'to hang soccer shoes over a wedge', but they are rare.

3 Though there are persuasive claims that $o$ - and $o b$ - are different forms of the same prefix, e.g. Šarić and Mikolić (2016), for the purposes of teaching CL2 they are usually considered separate prefixes, e.g. Udier and Gulešić Machata (2014). 


\begin{tabular}{|c|c|c|c|c|}
\cline { 2 - 5 } \multicolumn{1}{c|}{} & $1^{\text {st }}$ group & $2^{\text {nd }}$ group & $3^{\text {rd }}$ group & $4^{\text {th }}$ group \\
\hline explanation & $\begin{array}{c}\text { cognate pre- } \\
\text { position exists } \\
\text { and follows the } \\
\text { prefixed verbs in } \\
\text { a sentence }\end{array}$ & $\begin{array}{c}\text { cognate prepo- } \\
\text { sition exists but } \\
\text { does not follow } \\
\text { the prefixed verb } \\
\text { in a sentence }\end{array}$ & $\begin{array}{c}\text { cognate prepo- } \\
\text { sition exists but } \\
\text { it (almost) never } \\
\text { follows the pre- } \\
\text { fixed verbs in a } \\
\text { sentence }\end{array}$ & $\begin{array}{c}\text { cognate pre- } \\
\text { position does } \\
\text { not exist, but a } \\
\text { preposition with } \\
\text { similar meaning } \\
\text { might exist }\end{array}$ \\
\hline prefixes & $\begin{array}{c}n a-, \text { od-, s-, } \\
u-, z a-\end{array}$ & $\begin{array}{c}n a-, \text { od-, s-, } \\
u-, z a-\end{array}$ & $\begin{array}{c}\text { nad-, o-, po-, } \\
\text { pred-, pri- }\end{array}$ & $\begin{array}{c}\text { ob-, pre-, pro-, } \\
\text { su-, raz- }\end{array}$ \\
\hline $\begin{array}{c}\text { cognate preposi- } \\
\text { tion exists }\end{array}$ & + & + & + & - \\
\hline $\begin{array}{c}\text { cognate preposi- } \\
\text { tion follows the } \\
\text { verbs }\end{array}$ & + & + & + & - \\
\hline $\begin{array}{c}\text { cognate prepo- } \\
\text { sition does not } \\
\text { follow the verbs }\end{array}$ & - & + & - & \\
\hline $\begin{array}{c}\text { cognate preposi- } \\
\text { tion follows some } \\
\text { of the verbs } \\
\text { formed by that } \\
\text { prefix }\end{array}$ & does not apply & + & & \\
\hline
\end{tabular}

Table 1: Groups of prefixed verbs and their features

The prefixed verbs were included in the questionnaire according to the following criteria: (1) they are not among the five most frequent verbs formed by a verbal prefix in question, (2) they do not designate any kind of self-movement (verbs of self-movement have a more salient spatial meaning, which makes them easier to understand, and they also appear chronologically early in teaching; that makes them well attained among CL2 students), (3) they are not reflexive verbs (because it would not be possible to find three distractors for each tested verb), (4) their aspectual pair was not already used in the questionnaire (e.g. zahvaliti 'to thank' and zahvaljivati 'to be thanking', (5) if they are prefixed by a verbal prefix which has a cognate preposition, then they are prefixed by verbal prefixes $n a-, o d-, s^{-}, u$ - and $z a$ - (those verbal prefixes were chosen based on the frequency of their cognate prepositions), (6) there is a possibility to find three distractors to form a valid test item ${ }^{4}$ (the questionnaire was pre-tested to eliminate the possibility that there is a context in which the use of a distractor was possible, i.e. each test item had only one possible answer as prefixed verbs with similar meanings, such as svezati 'to tie (with)' and zavezati 'to tie to', were avoided), and (7) prefixed verbs were selected according to their token frequency (the first step was to determine the token frequency of all verbs prefixed

4 CroDeriV database (Šojat, Srebačić and Štefanec 2013) was used to confirm that all of the distractors are existing verbs. 
by a certain verbal prefix, and then all other above mentioned criteria were applied). The verbs used in this research are presented in Table 2.

\begin{tabular}{|c|c|c|c|}
\hline $1^{\text {st }}$ group & $2^{\text {nd }}$ group & $3^{\text {rd }}$ group & $4^{\text {th }}$ group \\
\hline natjerati & najaviti & nadgledati & obrasti \\
nastupiti & napustiti & nadigrati & obavijati \\
nagovoriti & narasti & nadjačati & obložiti \\
oduzeti & odigrati & održati & prenijeti \\
odvojiti & odnijeti & ostaviti & pretjerati \\
odmoriti & odgoditi & obavljati & preliti \\
spadati & saznati & pokazivati & progurati \\
spustiti & spriječiti & postaviti & progristi \\
srušiti & steći & podržati & proigrati \\
uključiti & upravljati & predbaciti & surađivati \\
upisati & uslijediti & predviđati & suživjeti \\
uložiti & ugledati & predbilježiti & suglasiti \\
zaraditi & zatražiti & prijaviti & razraditi \\
zamijeniti & zamisliti & pridružiti & rasplakati \\
zamoliti & zatvoriti & privući & rastaviti \\
\hline
\end{tabular}

Table 2: Verbs used in the research

\section{RESEARCH RESULTS}

The research results are presented in Figure 2, which shows the total attainment of prefixed verbs according to the group of prefixed verbs they belong to, while Table 3 summarizes the findings according to the hypotheses made.

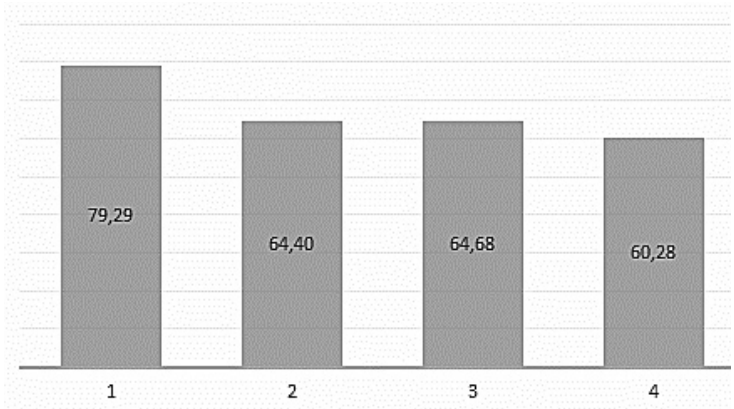

Figure 2: Attainment for groups of prefixed verbs (in \%) 


\begin{tabular}{|c|l|c|}
\hline hypothesis & \multicolumn{1}{|c|}{ explanation } & confirmed \\
\hline $\mathrm{H} 1$ & $\begin{array}{l}\text { The best attained prefixed verbs are those formed by a verbal prefix } \\
\text { which has a cognate preposition and that frequently occur in a sen- } \\
\text { tence with that cognate preposition following them. }\end{array}$ & + \\
\hline $\mathrm{H} 2$ & $\begin{array}{l}\text { Prefixed verbs formed by a verbal prefix which has a cognate preposi- } \\
\text { tion but that never occur in a sentence with that cognate preposition } \\
\text { following them, will be less well attained than prefixed verbs formed } \\
\text { by a verbal prefix which has a cognate preposition and that frequently } \\
\text { occur in a sentence with that cognate preposition following them. }\end{array}$ & + \\
\hline H3 & $\begin{array}{l}\text { Among prefixed verbs formed by a verbal prefix which has a cogna- } \\
\text { te preposition but that never occur in a sentence with that cognate } \\
\text { preposition following, verbs prefixed by a verbal prefix which more } \\
\text { frequently co-occurs with its cognate preposition will be better at- } \\
\text { tained. }\end{array}$ & \\
\hline \multirow{2}{*}{ H4 } & $\begin{array}{l}\text { Prefixed verbs formed by a verbal prefix which does not have a cog- } \\
\text { nate preposition will be least well attained even if a preposition with } \\
\text { a meaning similar to the verbal prefix exists. }\end{array}$ & + \\
\hline
\end{tabular}

Table 3: Summary of findings

Verbs that belong to the first group, i.e. the verbs prefixed by verbal prefixes which have cognate prepositions and that frequently occur in a sentence with the cognate prepositions following them, showed the highest degree of attainment. The total attainment of such verbs is $79.29 \%$, by which $\mathrm{H} 1$ is confirmed. All verbal prefixes used to form prefixed verbs in this group were rather evenly attained ( $\mathrm{na}-81.56 \%$, od $-86.52 \%, s-68.79 \%$, $u-75.89 \%, z a-83.69 \%$ ) i.e. there is no great difference in the levels of their attainment. This puts forward a claim that the attainment is characteristic for the whole group, and not for a certain prefix(es). Among all of the verbs in this group, the verb zamoliti 'to ask' is best attained with $97.87 \%$.

The second group of prefixed verbs, i.e. the verbs prefixed by verbal prefixes which have cognate prepositions but that never occur in a sentence with that cognate preposition following them (there is, however, a whole series of other verbs prefixed by the same verbal prefix and followed by a cognate preposition), was less attained than the first group. The total attainment of such verbs is $64.40 \%$, by which $\mathrm{H} 2$ is confirmed. It should be noted that the verbal prefix $u$ - was least attained in this group. Verbs formed by this verbal prefix showed an attainment of only $47.52 \%$. In general, the attainment results are rather uneven (na-72.34\%, od-56.03\%, s- 68.09\%, u- 47.52\%, za-78.01\%) and the difference between the best attained prefix and the least attained prefix is much greater than the difference in the first group of verbs. The verb zatvoriti 'to close' was the best attained out of all the prefixed verbs within this group with an attainment of $91.49 \%$.

The third group of prefixed verbs, i.e. the verbs prefixed by verbal prefixes which have cognate prepositions but that (almost) never occur in a sentence with that cognate preposition following (and this is characteristic of all verbs formed by those verbal 
prefixes), showed an attainment of $64.68 \%$. This means that prefixed verbs from the third group were better attained than verbs from the second group and by this H3 was not confirmed. It should be noted that in this group, as well as in the second group, verbal prefixes were rather unevenly attained, i.e. prefixes po- $(79.43 \%)$ and $o$ - $(72.34 \%)$ were better attained than prefixes nad- $(56.03 \%)$, pred- $(47.52 \%)$ and pri- $(68.09 \%)$. The verb ostaviti 'to leave' and postaviti 'to set, to appoint' were the best attained of all with the $85.11 \%$.

The fourth group of verbs, i.e. verbs prefixed by verbal prefixes which do not have cognate prepositions, was least attained, as expected. The total attainment of such verbs is $60.28 \%$, and by this $\mathrm{H} 4$ is confirmed. Results according to specific verbal prefixes are even more uneven than in the previous two groups. The best attained verbal prefix was su- $(82.98 \%)$ followed by raz- $(70.92 \%)$ and pre- $(61.70 \%)$ while the least attained were pro- $(46.10 \%)$ and $o b-(39.72 \%)$.

When all verbs are taken into account, it can be said that the best attained verbs belong mostly to the first group of prefixed verbs, as presented in the left side of Table 4 . On the other hand, the least attained verbs belong mostly to the fourth group of verbs, as presented in the right side of Table 4.

\begin{tabular}{|c|c|c|c|c|c|}
\hline \multicolumn{3}{|c|}{ best attained verbs } & \multicolumn{3}{c|}{ least attained verbs } \\
\hline verb & attainment & group & verb & attainment & group \\
\hline zamoliti & $97.87 \%$ & 1 & obavijati & $21.28 \%$ & 4 \\
\hline surađivati & $95.74 \%$ & 4 & uslijediti & $23.40 \%$ & 2 \\
\hline zaraditi & $93.62 \%$ & 1 & odnijeti & $25.53 \%$ & 2 \\
\hline odmoriti & $93.62 \%$ & 1 & predbilježiti & $25.53 \%$ & 3 \\
\hline zatvoriti & $91.49 \%$ & 2 & progristi & $31.91 \%$ & 4 \\
\hline prenijeti & $91.49 \%$ & 4 & nadgledati & $34.04 \%$ & 3 \\
\hline odvojiti & $91.49 \%$ & 1 & proigrati & $34.04 \%$ & 4 \\
\hline saznati & $89.36 \%$ & 2 & obrasti & $40.43 \%$ & 4 \\
\hline nastupiti & $89.36 \%$ & 1 & preliti & $42.55 \%$ & 4 \\
\hline zamisliti & $89.36 \%$ & 2 & spriječiti & $46.81 \%$ & 2 \\
\hline
\end{tabular}

Table 4: Best and least attained verbs

\section{$7 \quad$ DISCUSSION}

As the results showed, verbs prefixed with a prefix which has a cognate preposition and that are also followed by that preposition in a sentence are attained best out of all prefixed verbs in the research. The level of their attainment is $79.29 \%$. That is in line with expectations as the prepositions directly refer to the meaning, or, to be more precise, reinforce 
or highlight (Brala-Vukanović and Rubinić 2011) the (spatial) meaning of their cognate verbal prefixes when they follow them in a sentence. Constructions such as $u c ́ i u$ 'to get in', napisati na 'to write (on)', skočiti s 'to jump off' etc. are both very frequent and semantically transparent and, consequently, well attained among CL2 students.

Among the results belonging to the first group of prefixed verbs two details require additional comment. Prefix $s$ - has the lowest percentage of attainment (68.79\%) and that can be explained by that its cognate preposition $s$ 'off, with' has two rather disconnected meanings - the ablative meaning 'off' when used with the genitive and the comitative/ sociative meaning 'with' when used with the instrumental (see Matovac 2017 for more detailed discussion on this topic). Due to the fact that token frequency was one of the factors that influenced the list of prefixed verbs considered to be included in this research, $s$-verbs included in this research had only the ablative meaning. Nevertheless, the most common and salient meaning of the preposition $s$ is the comitative/sociative one (Matovac 2017: 119). CL2 students have been connecting the prefix $s$-with the comitative/ sociative meaning of the preposition $s$, which resulted in a weaker attainment of $s$-verbs. Of all the verbs in the first group, the best attained verb was zamoliti 'to ask' (97.87\%), which can be attributed to its pragmatic value. CL2 students are acquainted with it very early, almost as soon as they start to learn the language, e.g. when they learn formulaic expressions such as Mogu li zamoliti za... 'May I ask for...' etc.

As for verbs prefixed by verbal prefixes which have cognate prepositions but that never occur in a sentence with that cognate preposition following them (there is, however, a whole series of other verbs prefixed by the same verbal prefixes and followed by a cognate preposition), their level of attainment is $64.40 \%$. This is a lower attainment than among verbs in the first group and this strongly speaks in favor of the premise that the correct interpretation of the meaning of a prefixed verb is strongly supported by an understanding of the meaning of the cognate preposition as well as co-occurrence of that preposition with the verbal prefix. When the preposition does not appear, prefixed verbs are harder to properly interpret. It should be noted that $u$-verbs are least well attained and their attainment is only $47.52 \%$. It needs to be pointed out that u-verbs used in this research were the verbs ugledati 'to catch sight of', upravljati 'to steer, to govern, to rule, to manage' and uslijediti 'to follow'. Just as with $s$-verbs in the first group, this can be attributed to that the meaning of the verbal prefix $u$ - in those verbs is quite remote from the prototypical meaning of the preposition $u$ 'in' (see Šarić 2014 for more detailed discussion on the meaning of the verbal prefix $u$ - and Šaric 2008 for more detailed discussion on the meaning of the preposition $u$ ). $U$-verbs with a prototypical prefix meaning supposedly should be better attained, but that has yet to be proven correct by a separate study which should focus especially on the relationship between the prototypicality of the meaning of verbal prefixes and the attainment of prefixed verbs. Furthermore, in the second group of prefixed verbs the results are much less even than the results obtained for the first group (the first group: $n a-81.56 \%$ od $-86.52 \%, s-68.79 \%, u-75.89 \%$ and $z a-83.69 \%$ vs. the 
second group: $n a-72.34 \%$, od- $56.03 \%, s-68.09 \%, u-47.52 \%$ and $z a-78.01 \%$ ) and the difference between the best attained prefix and the least attained prefix in the second group is much larger than in the first group of prefixed verbs. This shows that a lack of co-occurrence of the cognate preposition does not have the same effect on interpretation of all prefixes, which probably has to do with the complexity of the semantic network and with the token frequencies of both verbal prefixes and their cognate prepositions. The verb zatvoriti 'to close', again probably due to pragmatic reasons, e.g. zatvoriti vrata 'to close the door' or trgovina je zatvorena 'the shop is closed', is the best attained of all the prefixed verbs within this group with $91.49 \%$ attainment.

When it comes to verbs formed by the verbal prefixes nad-, o-, po-, pred- and pri-, i.e. the verbs prefixed by verbal prefixes which have cognate prepositions but that (almost) never occur in a sentence with those cognate prepositions following (and this is characteristic of all verbs formed by those verbal prefixes) had a level of attainment of $64.68 \%$. When compared with the level of attainment of the second group of verbs, i.e. verbs prefixed by verbal prefixes which have cognate prepositions but that never occur in a sentence with that cognate preposition following them (there is, however, a whole series of other verbs prefixed by the same verbal prefixes and followed by a cognate preposition), which was $64.40 \%$, it turns out that the difference of just $0.28 \%$ between the two groups was too small to really prove any difference. Therefore, it could be concluded that verbs from the second group and verbs from the third group were approximately equally well attained. The small difference measured, however, could also indicate that CL2 students have a tendency, a small one, to better understand verbs prefixed by verbal prefixes which are never followed by their cognate prepositions than those which sometimes do appear followed by their cognate prepositions. That leads to the conclusion that when the co-occurrence of the cognate preposition is expected, but the preposition does not appear, it confuses CL2 students and induces them to make a wrong conclusion on the correct interpretation of the meaning of a prefixed verb. The best attained verbs of the third group are ostaviti 'to leave', postaviti 'to set' and pokazivati 'to show' with an attainment of more than $80 \%$. That finding works in favor of the claim that frequency is more important in the process of attainment than the semantic transparency as those verbs are the second, third and fourth most frequent of all the prefixed verbs used in this research, as presented in Table 5 (the majority of the most frequent verbs belong to the third group). It could be concluded that CL2 students attained them based on their collocational context and usage frequency. Nevertheless, that the frequency does not provide the full explanation can be seen from the low level of attainment of the verb održati 'to keep, to hold, to maintain', which is the most frequent verb used in this research. The low level of attainment of the verb prijaviti 'to apply, to register, to report, to check in, to log in, to turn in' is not surprising as in this research only non-reflexive forms were used and the verb prijaviti is mostly used with the reflexive se. Prijaviti se has a strong pragmatic value in the everyday life of a student, e.g. prijaviti se za stipendiju 'to apply for a scholarship', prijaviti 
se na mejl 'to log in to an e-mail account' etc. In this research the lack of se probably confused students and caused a rather low level of attainment for this verb.

\begin{tabular}{|c|c|c|}
\hline verb & token frequency & attainment \\
\hline održati & 343736 & $57.45 \%$ \\
\hline postaviti & 259574 & $85.11 \%$ \\
\hline ostaviti & 239330 & $85.11 \%$ \\
\hline pokazivati & 236624 & $80.85 \%$ \\
\hline najaviti & 201758 & $63.83 \%$ \\
\hline odigrati & 145132 & $78.72 \%$ \\
\hline uključiti & 142577 & $74.47 \%$ \\
\hline prijaviti & 136236 & $53.19 \%$ \\
\hline upisati & 121752 & $76.60 \%$ \\
\hline saznati & 121221 & $89.36 \%$ \\
\hline
\end{tabular}

Table 5: Most frequent verbs used in this research and their attainment

It should be noted that not all verbal prefixes in this group were evenly attained; the prefixes po- $(79.43 \%)$ and $o-(72.34 \%)$ were better attained than the prefixes nad$(56.03 \%)$, pred- $(47.52 \%)$ and pri- $(68.09 \%)$. If the frequencies of those verbal prefixes, presented in Table 6, are taken into account then the connection between the frequency and the attainment of a verbal prefix is clearly identified. A conclusion emerges that in the third group of verbs, where there is a lack of co-occurrence of cognate prepositions and verbal prefixes, attainment is supported by other factors, e.g. a high frequency of prefixed verbs and verbal prefixes, a strong spatial meaning of verbal prefixes and a lack of complexity in the semantic networks of verbal prefixes and their cognate prepositions (see Udier and Matovac (2017) for more detail on this topic).

\begin{tabular}{|c|c|c|}
\hline prefix & token frequency & attainment \\
\hline po- & 11905820 & $79.43 \%$ \\
\hline o- & 7474459 & $72.34 \%$ \\
\hline pri- & 3116380 & $68.09 \%$ \\
\hline pred- & 921858 & $56.03 \%$ \\
\hline nad- & 105375 & $47.52 \%$ \\
\hline
\end{tabular}

Table 6: Frequency of verbal prefixes and their attainment

In the fourth group of verbs, formed by the prefixes ob-, pre-, pro-, su- and raz-, i.e. in the group of verbs prefixed by verbal prefixes which do not have cognate prepositions, 
as expected, the level of attainment was the lowest, $60.28 \%$ in total. Such a result clearly confirms the importance of cognate prepositions in the understanding of verbal prefixes and prefixed verbs. CL2 students are less capable of understanding prefixed verbs whose meaning is not supported by an understanding of the meaning of the preposition cognate to the verbal prefix used in their formation. Prepositions are taught much earlier than verbal prefixes (some of them, such as $i z$ 'out of' and $u$ 'in', are taught from the very beginning, literally from the first encounter of CL2 students with the Croatian language), which makes CL2 students well prepared when they start learning cognate verbal prefixes.

\section{CONCLUSION}

The research presented in this paper has shown that the attainment of prefixed verbs among CL2 students at the $\mathrm{B} 2$ and $\mathrm{C} 1$ levels of language proficiency is directly related to whether prepositions exist which are cognate to the verbal prefixes used to form prefixed verbs and to whether the cognate prepositions follow the prefixed verbs when used in a sentence. The mere existence of a preposition cognate to the verbal prefix used to form a prefixed verb is enough to aid in the attainment of prefixed verbs while the co-occurrence of a verbal prefix and its cognate preposition in a sentence has proven to be a great helping tool in the attainment of prefixed verbs, as such constructions are semantically more transparent and, consequently, easier to understand and memorise. Based on the results of this research, prepositions should be systematically used as a starting point in teaching verbal prefixation in CL2. However, the research indicated that several other factors can influence the attainment of prefixed verbs too, e.g. frequency, semantic transparency or complexity of meaning. Furthermore, the results indicated that pragmatic aspects of prefixed verbs need to be taken into account as well. Further analysis of those factors remains beyond the scope of this research, but first attempts in their interpretation can be found in Udier and Matovac (2017).

The results of this study provide the basic input needed to address the complex issue of the order in which verbal prefixation should be taught in CL2. The following conclusions can be drawn.

(1) Verbal prefixes which have cognate prepositions should be taught before verbal prefixes which do not have cognate prepositions, e.g. uć $i$ 'to enter' before proć $i$ 'to pass' because the preposition $u$ 'in' exists while the preposition *pro does not.

(2) When it comes to teaching verbal prefixes which do have cognate prepositions, the teaching should begin with prefixed verbs which are frequently followed by the preposition cognate to the verbal prefix used to form them while verbal 
prefixes which do have cognate prepositions, but verbs formed by them are never followed by those prepositions should follow, e.g. ući 'to enter' before nadić $i$ 'to surpass' because the preposition $u$ 'in' frequently follows $u c ́ i$ and the preposition nad 'over, above' never follows nadići.

(3) When teaching a particular verbal prefix, one should start with prefixed verbs which are followed by the preposition cognate to the prefix, and then continue with verbs which are not followed by the preposition cognate to the prefix, e.g. sići 'to get off' before spakirati 'to pack' because sići frequently appears with the preposition $s$ 'off, with' while spakirati does not appear with it.

Further studies should focus on the order in which verbs prefixed by verbal prefixes which do not have cognate prefixes should be taught, depending on whether they have prepositions with a similar meaning and depending on whether these prepositions appear after other verbs prefixed by those verbal prefixes when used in a sentence, e.g. should the prefix pro- be taught sooner than raz-as the prefix pro-frequently co-occurs with the preposition $k r o z$ 'through' while the prefix raz- has no co-occurring preposition at all.

\section{REFERENCES}

BABIĆ, Stjepan (2002) Tvorba riječi u hrvatskome književnom jeziku. $3^{\text {rd }}$ ed. Zagreb: Hrvatska akademija znanosti i umjetnosti, Nakladni zavod Globus.

BARIĆ, Eugenija/Mijo LONČARIĆ/Dragica MALIĆ/Slavko PAVEŠIĆ/Mirko PETI/ Vesna ZEČEVIĆ/Marija ZNIKA (1997) Hrvatska gramatika. Zagreb: Školska knjiga.

BRALA-VUKANOVIĆ, Maja/Nensi RUBINIĆ (2011) Prostorni prijedlozi i prefiksi u hrvatskome jeziku. Kognitivnosemantička analiza. Fluminensia 23 (2): 21-37.

LJUBEŠIĆ, Nikola/Tomaž ERJAVEC (2011) hrWaC and slWaC: Compiling Web Corpora for Croatian and Slovene. I. Habernal and V. Matoušek (eds.), TSD'11: Proceedings of the 14th international conference on Text, Speech and Dialogue. Berlin, Heidelberg: Springer, 395-402.

MATOVAC, Darko (2015) Kognitivnolingvistički pristup poučavanju glagolskih prefiksa u hrvatskom kao inom jeziku. K. Cergol Kovačević and S. L. Udier (eds.), Applied Linguistics Research and Methodology. Book of Abstracts. Zagreb: Srednja Europa, Hrvatsko društvo za primijenjenu lingvistiku, 63.

MATOVAC, Darko (2017) Prijedlozi u hrvatskome jeziku: Značenje, prostorni odnosi $i$ konceptualizacija. Zagreb: Hrvatska sveučilišna naklada.

MATOVAC, Darko/Sanda Lucija UDIER (2016a) Modeli poučavanja značenja glagolskih prefikasa i prefigiranih glagola u nastavi hrvatskoga kao inoga jezika. Jezikoslovlje 17 (3): 495-518. 
MATOVAC, Darko/Sanda Lucija UDIER (2016b) Istraživanje učinkovitosti poučavanja glagolske prefiksacije u nastavi hrvatskoga kao inog jezika kognitivnolingvističkom metodom. D. Stolac and A. Vlastelić (eds.), Language in Research and Teaching. Book of Abstracts. Zagreb: Srednja Europa, Hrvatsko društvo za primijenjenu lingvistiku, 51.

SILIĆ, Josip/Ivo PRANJKOVIĆ (2005) Gramatika hrvatskoga jezika za gimnazije i visoka učilišta. Zagreb: Školska knjiga.

ŠARIĆ, Ljiljana (2008) Spatial concepts in Slavic: a cognitive linguistic study of prepositions and cases. Wiesbaden: Otto Harrassowitz Verlag.

ŠARIĆ, Ljiljana (2014) Prostor u jeziku i metafora: Kongnitivnolingvističke studije o prefiksima i prijedlozima. Zagreb: Naklada Jesenski i Turk.

ŠARIĆ, Ljiljana/Petra MIKOLIĆ (2016) A semantic analysis of the verbal prefix o(b)- in Croatian. Croatica et Slavica Iadertina 11 (2): 249-283.

ŠOJAT, Krešimir/Matea SREBAČIĆ/Vanja ŠTEFANEC (2013) CroDeriV and the morphological analysis of Croatian verb. Suvremena lingvistika 39 (75): 75-96.

UDIER, Sanda Lucija/Milvia GULEŠIĆ MACHATA (2014) Razgovarajte s nama! Gramatika i pravopis hrvatskoga jezika s vježbama za razine B2-C1. Zagreb: FF press.

UDIER, Sanda Lucija/Darko MATOVAC (2017) Prototipnost i čestotnost u poučavanju glagolske prefiksacije. D. Stolac and A. Vlastelić (eds.), Language and Its Effects. Book of Abstracts. Zagreb: Srednja Europa, Hrvatsko društvo za primijenjenu lingvistiku, 90.

UDIER, Sanda Lucija/Nives MIKELIĆ PRERADOVIĆ/Damir BORAS (2017) Verb prefixes in teaching Croatian as a second language. K. Cergol Kovačević and S. L. Udier (eds.), Applied Linguistics Research and Methodology. Proceedings from the 2015 CALS conference. Frankfurt am Main: Peter Lang Publishing, 153-170.

\section{POVZETEK}

\section{V katerem vrstnem redu naj se poučuje raba glagolskih predpon $v$ hrvaščini kot drugem jeziku?}

V zadnjem času je zanimanje za poučevanje rabe glagolskih predpon v kontekstu hrvaščine kot drugega jezika naraslo. Eno od vprašanj, ki se pojavljajo, se nanaša na vrstni red poučevanja glagolskih predpon, s pomočjo katerega bi bilo poučevanje bolj učinkovito. V raziskavi, ki je bila izvedeni z učenci hrvaščine kot tujega jezika na ravneh B2 ter $\mathrm{C} 1$, smo preizkusili hipotezo, po kateri je razumevanje pomena glagolske predpone močno podprto $\mathrm{z}$ razumevanjem pomena soodvisnega predloga in neposredno vezano na to, ali se glagolska predpona pojavlja skupaj s svojim soodvisnim predlogom, ko je glagol s predpono uporabljen v stavku. Glede na rezultate raziskave 
smo prišli do zaključkov o zaporedju, v katerem naj bi se poučevanje glagolskih predpon v CL2 izvajalo.

Ključne besede: glagolske predpone, glagoli s predpono, hrvaščina kot drug in tuj jezik, pristop k učenju

\begin{abstract}
Teaching verbal prefixation in the context of Croatian as a second language (CL2) has been receiving an increasing amount of attention recently, and one of the questions which has come up has to do with the order in which verbal prefixation should be taught for the teaching to be more effective. To answer this question, this research, conducted among CL2 learners at the B2 and C1 levels of language proficiency, tests the hypothesis that an understanding of the meaning of a verbal prefix is strongly supported by understanding the meaning of its cognate preposition and directly related to whether a verbal prefix co-occurs with its cognate preposition when a prefixed verb is used in a sentence. Based on the research results conclusions were drawn on the order in which the teaching of verbal prefixation in the CL2 classroom should progress.
\end{abstract}

Key words: verbal prefixes, prefixed verbs, Croatian as a second and foreign language, teaching approach 